\title{
LA SUBVERSION DE LA ADAPTACION LITERARIA EN TRISTANA Y ESE OSCURO OBJETO DEL DESEO DE LUIS BUÑUEL
}

\author{
ARNAUD DUPRAT \\ Université Rennes 2
}

\begin{abstract}
Resumen
Tristana y Ese oscuro objeto del deseo son las dos últimas adaptaciones literarias de Luis Buñuel. Aunque el cineasta se permita varios cambios -cortes, síntesis, añadidos- en estas historias al trasladarlas de la novela a la pantalla, produciendo así obras típicamente buñuelianas, los textos literarios de Benito Pérez Galdós y Pierre Louÿs parecen seguir presentes como una referencia reivindicada en las películas. Primero, los diálogos fílmicos se parecen mucho a los de las dos novelas. Se nota lo novelesco en varias réplicas que, demasiado literarias, suenan extrañas. Del mismo modo, si podemos reconocer en las heroínas fílmicas a sus antecedentes literarios como una referencia original, el director provoca este reconocimiento sólo para atraernos mejor en un universo que se vuelve inquietante y que interroga nuestras representaciones y creencias, gracias a sutiles desplazamientos de sentido. Estos textos resisten al proceso de la adaptación y permanecen en el filme bajo la forma de citas, como otro texto, de manera a priori inalterada. Tristana y Ese oscuro objeto del deseo plantean entonces la problemática de la función que puede asegurar la obra literaria adaptada en la escritura del texto fílmico y en la subversión que propone éste del discurso cinematográfico.
\end{abstract}

\section{Palabras clave}

Buñuel, Galdós, Louys, Adaptación, Intertextualidad

Abstract
Tristana and That Obscure Object of Desire are the last literary adaptations by Luis Buñuel. Even if the director takes the liberty of making various changes -cuts, synthesis, additions - in the adaptation process, to create Buñuelian works, the literary texts by Benito Pérez Galdós and Pierre Louÿs seem to be still presents in the films as a claimed reference. Firstly, the cinematic lines look like the literary dialogues and sound strange on the screen. In the same way, if we recognize the literary heroines in the cinematic characters as an original reference, the director creates this recognition only to draw us to an universe which becomes disturbing and questions our comprehension and believes, thanks to skilful meaning modifications. These texts resist the adaptation process and remain in the films as quotations, as another texts, in a unmodified way. Therefore Tristana and That Obscure Object of Desire pose the question of the novel's function in the filmic work's creation and in its subversion of the cinematic discourse.

$$
\text { Key Words }
$$

Buñuel, Galdós, Louys, Adaptation, Intertextuality

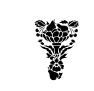


Tristana y Ese oscuro objeto del deseo son las dos últimas adaptaciones lit-erarias de Luis Buñuel. Hasta entonces, las novelas que el director había llevado a la pantalla -salvo el caso de Cumbres borrascosas - eran obras que le gustaban poco. Así lo explicaba: «Cuando filmo una novela, me siento más libre si no es una obra maestra, porque así no me cohíbo para transformar y meter todo lo que quiero ${ }^{1} . »$ Sin embargo, a pesar de que Buñuel calificara Tristana de «una de las peores novelas de Galdós» y precisara que «sólo le interesaba el detalle de la pierna cortada ${ }^{2}$ », el novelista español representaba para el cineasta como una referencia muy importante, ya que lo designó como «la única influencia que (...) reconocería ${ }^{3}$ ». En el caso de Ese oscuro objeto del deseo, Buñuel adapta La mujer y el pelele de Pierre Louÿs, que era una lectura de juventud apreciada y cuyo argumento -la pasión amorosa entre los protagonistas Mateo y Conchita- había influenciado al grupo surrealista que veía en ello un ejemplo perfecto del «amour fou».

De esta forma, si el cineasta se permite varios cambios en estas historias al trasladarlas de la novela a la pantalla -como solía hacer en sus adaptaciones anteriores-y produce así obras típicamente buñuelianas, en estos dos casos los textos literarios parecen seguir presentes como una referencia reivindicada en las películas.

Tristana y Ese oscuro objeto del deseo plantean entonces la problemática de la función que puede asegurar la obra literaria adaptada en la escritura del texto fílmico. Al evaluar los fenómenos de extrapolaciones en estas dos adaptaciones y al interesarnos más precisamente en los diálogos como en las dos heroínas fílmicas, intentaremos definir la adaptación buñueliana que parece oscilar entre clasicismo y subversión de los textos originarios.

\section{Adaptaciones hacia el universo buñueliano}

A pesar de escribir Tristana y Ese oscuro objeto del deseo con dos guionistas distintos - Julio Alejandro ${ }^{4}$ y Jean-Claude Carrière ${ }^{5}$-, estas adaptaciones de Buñuel presentan características comunes.

Primero, las dos son adaptaciones libres y presentan cambios geográficos y temporales importantes. Si las novelas se desarrollan al final del siglo XIX, la acción de Tristana tiene lugar con Buñuel en los años treinta en plena Segunda República, mientras que Ese oscuro objeto se desarrolla en los años setenta. Del mismo modo, la primera película abandona Madrid para trasladarse a Toledo y la segunda deja Andalucía por París, convirtiendo al protagonista Mateo en el francés Mathieu. Estos cambios manifiestan la necesidad para el cineasta de filmar una época y un lugar que conoce o ha conocido. Durante la Segunda República, Buñuel se encontraba en Madrid donde trabajaba como productor. Toledo, que califica en sus memorias como la "ciudad tan querida ${ }^{6}$ ", era una de sus visitas favoritas con 104

1 Tomás PEREZ TURRENT, José DE LA COLINA, Buñuel por Buñuel, Madrid, Plot ediciones, 1993, p.

2 Ibid, p. 155. Publicada en el año 1892, varios comentadores la consideraron como una obra menor de su autor. Emilia Pardo Bazán la definió como los «esbozos de una gran novela que no llega a escribirse y cuyo asunto sería la esclavitud moral de la mujer» (Citado en Benito PEREZ GALDOS, introducción de Ricardo Gullón, Tristana, Madrid, Alianza Editorial, 2000, (Colección «Biblioteca Pérez Galdós»), p. 7). Además, al multiplicar las analepsis en la primera parte, al mezclar con el relato primero el epistolar que convierte así a Tristana en enunciadora durante capítulos enteros, Galdós entrega aquí una novela con una estructura menos lograda que sus obras anteriores. Por fin, la novela es psicológica cuando los lectores coétanos esperaban una denuncia social

${ }^{3}$ Max AUB, Conversaciones con Buñuel, Madrid Aguilar, 1985, p. 118

${ }^{4}$ Guionista español con quien trabajó Buñuel en Abismos de pasión (1953), Naz̧arín (1958), Viridiana (1961) y Simón del desierto (1965).

${ }^{5}$ Guionista francés que colabora por primera vez con Buñuel en Diario de una camarera (1964). Han escrito juntos Belle de Jour (1967), La vía láctea (1969), El discreto encanto de la burguesía (1972), El fantasma de la libertad (1974).

${ }^{6}$ Luis BUNUEL, con la colaboración de Jean-Claude Carrière, Mi último suspiro, Barcelona, Plaza y Janes editores, 1982, p. 298. Julio Alejandro confirma también el papel importante de Toledo en Tristana: «Escribimos Tristana pensando de una manera definitiva en Toledo (...) Así que se pensó en la adaptación exactamente en 
sus amigos de la Residencia de estudiantes en los años veinte. En cuanto a La mujer y el pelele que, según Michel Delon, presenta «una tensión entre norte y sur, entre un cristianismo interiorizado y el paganismo, entre la modernidad económica y los valores clásicos ${ }^{7}$ », se desarrolla en Francia que ya ha sido escenario de las películas anteriores -El discreto encanto de la burguesía y El fantasma de la libertad- y en las que parecía simbolizar todo un mundo occidental moderno dominado por la sociedad de consumo y entretener relaciones conflictivas con los países más pobres.

Por supuesto, este fenómeno no es una particularidad propia de Buñuel sino que es definido por Francis Vanoye como una característica clásica de las adapta-ciones literarias al cine: «(Se trata) de la transferencia histórico-cultural, tan de-terminante. En efecto, la obra adaptada lo es siempre en un contexto histórico y cultural distinto de aquél en que ha sido producida ${ }^{8} . »$

Otro fenómeno clásico es el de reducción de la historia ${ }^{9}$. Con Buñuel, son sobre todo los acontecimientos más melodramáticos los que desaparecen. Ese oscuro objeto no nos cuenta los viajes solitarios que efectúa Mateo cada vez que se separa de Conchita, tampoco su relación con la bailarina italiana Giulia. En Tristana, Horacio no deja a la joven sola en Toledo para acompañar a su tía a Villajoyosa. El sufrimiento de la separación y el miedo al olvido expresado en las largas cartas de Tristana como en las numerosas visitas del pintor después de la operación desaparecen de la película. Las distintas fases psicológicas que vive la joven se limitan con Buñuel a un comportamiento cada vez más vindicativo. Este rechazo a lo melodramático se nota al final de la Tristana fílmica, aun-que el nuevo desenlace elegido por Buñuel y Alejandro hubiera podido lógica-mente pertenecer a este género. Si Galdós termina su novela con un tono irónico -cuando Lope, al enriquecerse y al tratar a curas, reniega de todos sus principios y que Tristana abandona también sus sueños de éxito para casarse con su tutor y llevar una vida burguesa frustrante, el relato acaba con una interrogación del narrador: «¿Eran felices los dos?... Tal vez ${ }^{10} »$, en la adaptación buñueliana Lope se muere de un infarto bajo la mirada de su esposa que se niega a ayudarle. Este cambio parece ser lógico en la medida en que los personajes de Buñuel desarrol-lan una relación mucho más masoquista y autodestructora que impide todo final resignado. Sin embargo, a Buñuel no le gustaba el valor melodramático de este final y por eso le añadió las imágenes retrospectivas que cierran la película:

El final de Galdós no me parecía bien, pero tampoco me gustaba el mío. Me mo-lestaba mucho que terminase con la muerte de don Lope, me parecía melodramáti-co, pero no podía ver otro final sino ése (...) Es un final «con coleta», no me desa-grada. Tal vez por eso metí una serie rápida de imágenes retrospectivas ${ }^{11}$.

Estas imágenes no presentan ningún sentido racional y borran todo efecto melodramático gracias al misterio que introducen en el texto fílmico ${ }^{12}$.

lugares determinados de Toledo. Estos lugares no son algo anecdótico en la película, sino que tienen una fuerza vital dentro del script. Creo que lo que es Toledo marca de tal manera la película que, a mi modo de ver, es muy difícil hacer esa película en otra parte.» Max AUB, op.cit., p. 398

7 Pierre LOUYS, édition de Michel Delon, La femme et le pantin, Paris, Gallimard, 1990, (Collection «Folio»), p. 15.

${ }^{8}$ Francis VANOYE, Scénarios modèles, modèles de scénarios, Paris, Nathan, 1991, (Collection «Nathan cinéma»), p.151.

9 Adoptamos aquí la distinción establecida por Genette entre historia, relato y narración: «Propongo (...) designar historia el significado o contenido narrativo $(. .$.$) relato propiamente dicho el significante, el enunciado,$ discurso o texto narrativo mismo, y narración el acto narrativo productor y, por extensión, el conjunto de la situación real o ficticia en la que tiene lugar.» Gérard GENETTE, Figures III, Paris, Seuil, 1972, (Collection «Poétique»), p. 72

${ }^{10}$ Benito PEREZ GALDOS, introducción de Ricardo Gullón, op.cit., p. 234.

11 Tomás PEREZ TURRENT, José DE LA COLINA, op.cit., p. 160.

12 Aceptan varias interpretaciones sin reconocer textualmente ninguna. Estas imágenes podrían significar, como lo ex-plicó Maurice Drouzy, que el relato que nos ha propuesto la película desde el principio de la 
Además, como en cualquier adaptación clásica, el fenómeno de reducción conlleva también el de concentración. Así, se reduce el desamor de Tristana y Horacio a una sola escena que consiste en la única visita del pintor a casa de Lope, del mismo modo que se resumen en dos escenas las numerosas visitas de Mathieu a Conchita en su apartamento de París. Por fin, desaparecen las referen-cias a los orígenes de los protagonistas. En Tristana no se habla de los trastornos psicológicos de la madre de la heroína ni de los problemas económicos del padre ${ }^{13}$. El cine de Buñuel no es psicológicamente explicativo y una sola situación concreta nos puede dar a constatar de la personalidad de un personaje. Por ejem plo, un breve encuentro en la calle con una joven resume el pasado donjuanesco de Lope que ocupa tantas páginas de la novela.

Se nota también este fenómeno de concentración en la última secuencia de Ese oscuro objeto. La mujer y el pelele se termina con una carta de Mateo que le pide a Conchita que vuelva a su lado, después de una larga separación provo-cada por varios engaños de la joven. Se resume este nuevo comienzo posible de la pareja en la película cuando, en la última secuencia, los dos protagonistas reproducen el esquema comportamental hecho de amor, de deseo y de rechazo que ha sido el suyo durante todo el filme. Sin embargo, su comportamiento en esta escena, sin ninguna referencia a un adulterio ni a cualquier acontecimiento dramático que nos permitiría entender e interpretar a los personajes, convierte este final en un momento de nuevo muy misterioso.

Las adaptaciones de Buñuel condensan y depuran las obras literarias adap-tadas. Por lo tanto, como lo subraya Francis Vanoye, «podríamos extrapolar de esta necesidad del corte y de la síntesis un modelo de la adaptación como reducción (...) Pero sería olvidar que la adaptación implica casi siempre los procedimientos inversos: añadidos, complementos, dilataciones ${ }^{14} \gg$. Si por una parte se reducen los relatos, por otra se encuentran éstos desarrollados, dilatados. En Tristana, se desarrolla la llegada de la joven a casa de su tutor y el principio de su relación ${ }^{15}$. Interviene la herencia de Lope mucho más temprano en la película para poner de relieve los sacrificios que realiza el héroe por su pupila. Como se rechazan todo efecto melodramático y todo elemento periférico, los relatos se concentran más en los personajes. Así, Lope cobra más importancia que en la novela de Galdós donde desaparecía casi por completo durante todo el episodio epistolar. Se establece un vínculo claro entre el personaje y el cineasta que aquí parece hacer un balance lúcido de la experiencia de la vejez. Como Flaubert al hablar de Mme Bovary, Buñuel declaró: «Sí, soy yo don Lope. Ha venido a ser mi historia. Muy liberal, muy anti-clerical al principio y, a la vejez, sentado en una camilla tomando chocolate (...) hablando con tres curas. Y la nieve, afuera ${ }^{16} . »$

proyección fuese el producto de la imaginación de la heroína (Leer: Maurice DROUZY, Luis Buñuel architecte du rêve, Paris, Lherminier, 1978, p. 190). Podría tratarse también de imágenes mentales producidas por Lope que recordaría su vida con Tristana antes de morirse. Sin embargo, el misterio provocado proviene sobre todo del hecho de que, al no tener ningún sentido racional, estas imágenes son lo que Santos Zunzunegui calificó como «la flagrante autonomía de la maquinaria fílmica» que vienen a contradecir el discurso hasta entonces coherente de la instancia enunciadora. Santos ZUNZUNEGUI, «La tentativa de lo imposible : sueño, alucinación y realidad en el cine de Luis Buñuel», in Chus TULEDILLA (comisaria), Juan J. VAZQUEZ (director científico), Luis Buñuel, los enigmas de un sueño, Gobierno de Aragón, 2000, pp. 81-98, p. 97

${ }_{13}$ Cuando va a buscar a Tristana en su casa, Lope le dice que su madre «fue muy buena» pero que no hubo «cabeza con menos seso tampoco». Después, nos enteramos, cuando Lope acude al cuarto de Tristana que acaba de tener una pesadilla, de que era un amigo de los padres ya que, cuando era pequeña su pupila, cada vez que lo veía, «huía como si hubiera visto el diablo»

${ }^{14}$ Francis VANOYE,Francis VANOYE, op.cit., p. 132

15 La novela de Galdós empieza cuando los dos personajes ya son amantes y la explicación de esta pareja tan disparatada nos es dada bajo forma de analéptica externa -según la terminología de Genette- e intercalada de manera anacrónica a la presentación de los padres de Tristana

${ }^{16}$ Max AUB, op.cit., p. 146. Por su parte, el ayudante de dirección Pierre Lary nos confió: «Cuando rodamos la película, Buñuel tenía casi setenta años. Se trataba de un personaje (Lope) anarquista e independiente que, al envejecer, perdía poco a poco su independencia y se comprometía con los que había combatido antes. Era como una película exorcista. La hacía para no caer en esto. Le interpelaba mucho el personaje» (Entrevista del 17 de septiembre de 2004). En cierta medida, Mathieu en Ese oscuro objeto tiene la misma dimensión. Se trata de 
Esta dimensión personal marca la presencia del cineasta detrás de la instancia enunciadora del texto fílmico. Sin embargo, Lope no es el único protag onista que permite al cineasta expresarse. En la misma película, el campanero -un personaje creado por Buñuel- tiene un discurso que remite a las propias declaraciones del director. Al añorar la pérdida de espiritualidad y el desarrollo del materialismo y del individualismo, el campanero le cuenta a Tristana: «(...) en los tiempos aquellos de mucha religión, la gente sabía las cosas por las campanas, y las obedecía (...) Hoy, ya son otros tiempos (...) La gente tiene prisa por buscar dinero. No escuchan.» Por su parte, Buñuel declaró: «(...) hoy lo sagrado cuenta muy poco. Aunque no seamos creyentes, podemos sentir esto como una pérdida ${ }^{17} . »$

Además, desde lo alto de la catedral, el campanero domina toda la ciudad como el cineasta se sitúa por encima de sus personajes. Se comentó varias veces que Buñuel los filmaba de manera científica, como un entomólogo que estudiara insectos. De hecho, muchas de sus escenas empiezan con planos generales en picado. El sentimiento proporcionado por la altura queda expresado por Francisco, el héroe de El, cuando lleva a su esposa Gloria a un campanario. Al enseñarle a la gente en la calle, le dice: «Aquí tienes a tu gente. Desde aquí se ve claramente lo que son : gusanos arrastrándose por el suelo. Me dan ganas de arrastrarlos con el pie $^{18} . »$ Aparece de nuevo el mismo sentimiento en la réplica de Tristana: «Aquí arriba, debe sentirse usted muy importante. ¡Es como si dominase el mundo!» Sin embargo, la respuesta del campanero subraya una evolución desde El: «A fuerza de ver siempre lo mismo, uno ya ni se fija. Y eso de importante, jmenos que un gato! (...) Antes, sí que éramos importantes, pero hoy en día... ${ }^{1}{ }^{\prime}$

Así, a través de sus últimas películas, Buñuel expresa sus sentimientos, y también sus preocupaciones a propósito del desarrollo negativo del mundo. En Ese oscuro objeto, la presencia excesiva de los actos terroristas que se amplifican paralelamente a la historia de Mathieu y Conchita, provocan en los personajes ciertos comentarios que remiten a la propia opinión del director sobre este tema. En el tren que lo lleva de Sevilla a Madrid, Mathieu confía preferir el tren al avión porque «(...) aujourd'hui, vous prenez l'avion pour Bruxelles et, à cause de deux jeunes gens très gentils, vous vous retrouvez dans le désert ${ }^{20} \gg$. Después, cuando Mathieu está comiendo con su primo Edouard, dice: «La bande à Bon not, c’est bien fini. Ceux-là au moins avaient un idéal. Avec des révolvers à barrillet, ils ont terrorisé Paris pendant plusieurs jours, ils étaient désintéressés, généreux... ${ }^{21} \gg$ Estas réplicas tienen el mismo sentido que las declaraciones de Buñuel:

El símbolo del terrorismo, inevitable en nuestro siglo, siempre me ha atraído; pero del terrorismo total, cuyo objetivo es la destrucción de toda sociedad, es decir de toda la especie humana. No tengo sino desprecio para aquellos que hacen del terrorismo un arma política al servicio de una causa cualquiera, por ejemplo, esos que matan a

un hombre frustrado y obsesionado que recuerda a Francisco, el héroe de El. A propósito de éste, Buñuel declaró: «Hay algo de mí en el protagonista» (Tomás PEREZ TURRENT, José DE LA COLINA, op.cit., p. 79). De Mathieu, dice: «(...) me interesaba (...) la historia de una obsesión que nunca puede hacerse realidad» (Ibid, p. 230).

17 Ibid., p. 139. Dijo también: «Y además las campanas. Las campanas de Calanda. Que tocan todo el día, ¿quién muere? Campanas, campanas a misa, al rosario, el toque de agonía. Iba mucho por el cementerio. Los huesos (...) Los carneros. Una visión de muerte continua y el sentido del pecado.» Max AUB, op.cit., p. 41

18 A propósito de esta escena, Buñuel declaró: «Comparto su sentimiento, cuando ve a la gente allá abajo, como hormigas, y que dice : "Me gustaría ser Dios para aplastarlos..."» Tomás PEREZ TURRENT, José DE LA COLINA, op.cit., p. 79

${ }^{19}$ Estas palabras remiten a las propias declaraciones del cineasta cuando, al comparar su época surrealista con sus últimas obras, dice que el surrealismo ha sido un fracaso ideológico porque -y cita a Breton- «el escándalo ya no existe». Luis BUNUEL, con la colaboración de Jean-Claude Carrière, op.cit., p. 136 y p. 149

20 «Hoy día uno coge el avión para Bruselas y, por culpa de dos jóvenes muy simpáticos, se encuentra en pleno desierto.»

21 «Se acabó con la banda de Bonnot. Por lo menos, éstos tenían un ideal. Con revólveres, aterrorizaron todo París durante varios días. Eran desinteresados, generosos... 
madrileños para llamar la atención del mundo sobre los problemas de Armenia. De esos terroristas ni hablo. Me dan horror ${ }^{22}$.

Si este fenómeno ha cobrado más importancia, es también por culpa de una mediatización excesiva que los vuelve comunes y tiende a una glorificación insana.

Lo que me indigna respecto a los terroristas, cualquiera que sea su filiación política, es que matan a la gente o amenazan con hacerlo, y las autoridades pactan con ellos, los periódicos les hacen una enorme publicidad, los convierten en estrellas de alguna manera. Esas noticias, yo las censuraría en todos los periódicos y en la televisión, si tuviera poder para ello. Hay exceso de información ${ }^{23}$.

Así, en el periódico que lee Mathieu, solamente se anuncian catástrofes de manera sensacionalista. En Sevilla, la radio informa de que un ataque bacteriológico y combates hicieron «de doscientos a trescientos víctimas civiles», mientras que en París, se anuncia la alianza de varios grupos de extrema-izquierda que prepara numerosos atentados. Si al principio de la película Edouard le dice a Mathieu que «les terroristes d'aujourd'hui sont fascinés par le danger, c'est clair. Certains ont une motivation politique. Mais la plupart aiment le risque, l'exploit. Tu verras que bientôt, dans les journaux, on parlera d'eux en rubrique sportive ${ }^{24} \gg$, se nota a lo largo del filme el efecto nefasto de estas informaciones excesivas en los protagonistas que acaban por no reaccionar al escucharlas.

\section{La resistencia de los textos literarios}

Todas estas reflexiones expresadas a través de los personajes, como la dimensión autobiográfica de algunos, tienen como resultado, lo hemos dicho, el de subrayar la presencia del cineasta y convertir estas películas en obras «buñuelianas» antes de adaptaciones cinematográficas de textos literarios de Galdós y Louÿs.

Por lo tanto, estos textos originarios no desaparecen. Siguen presentes gracias a los diálogos fílmicos que se parecen mucho a los de las dos novelas. Las diferencias existen pero son mínimas, y no impiden al espectador que haya leído las novelas antes de ver las películas, notar los parecidos y así recordar sus orígenes literarios.

Por ejemplo, cuando la Tristana galdosiana decide contarle a Horacio la verdad en cuanto a su relación con Lope, le dice al pintor:

Te estoy engañando y no debo ni quiero engañarte. La verdad se me sale a la boca, y no puedo contenerla más. No estoy casada con mi marido..., digo, con mi papá, digo con ese hombre. Un día y otro pensaba decírtelo ; pero no me salía, hijo, no me salía... Ignoraba, ignoro aún, si lo sientes o te alegras, si valgo más o valgo menos a tus ojos... Soy una mujer deshonrada, pero soy libre. ¿Qué prefieres?... ¿Que sea una casada infiel o una soltera que ha perdido su honor? De todas maneras creo que al decírtelo, me lleno de oprobio..., y no sé..., no sé... ${ }^{25}$

Después, Tristana añade:

¿Me quieres menos o me quieres más? Dime que más, siempre más. Es rigor de verdad, debo parecerte ya menos culpable, porque no soy adúltera ; no engaño sino a quien no tiene derecho a tiranizarme. Mi infidelidad no es tal infidelidad, ¿qué te parece?, sino castigo de su infamia ; y este agravio que de mí recibe se lo tiene merecido ${ }^{26}$.

22 Ibid, p. 152. Jean-Claude Carrière dijo a propósito de esta película: «Algunas réplicas que dice Fernando (Rey) en Ese oscuro objeto podrían ser dichas por el propio Buñuel. Cuando las oigo, oigo la voz de Buñuel.» Entrevista de la edición DVD estadounidense (Zona 1) de Ese oscuro objeto del deseo (The Criterion Collection, 2001).

23 Tomás PEREZ TURRENT, José DE LA COLINA, op.cit., p. 169.

24 «Queda muy claro que a los terroristas de hoy les atrae el peligro. Algunos tienen motivaciones políticas, pero a la mayoría le gusta el riesgo, la hazaña. Ya verás que dentro de poco se hablará de ellos, en los periódicos, en la sección de los deportes.»

25 Benito PEREZ GALDOS, introducción de Ricardo Gullón, op.cit., p. 101

${ }^{26}$ Ibid, p. 102. 
Por fin, concluye:

desde que te conocí empecé a sentir hacia él un terrible desvío... Después... ¡Ay, Jesús, me pasan cosas tan raras...! A veces paréceme que le aborrezco, que siento hacia él un odio tan grande como el mal que me hizo ; a veces..., todo te lo confieso, todo... siento hacia él cierto cariño, como de hija, y me parece que si él me tratara como debe, como un padre, yo le querría... Porque no es malo, no vayas a creer que es muy malo... No ; allí hay de todo : es una combinación monstruosa de cualidades buenas y de defectos horribles ${ }^{27}$.

En la réplica de la Tristana buñueliana, observamos un fenómeno de concentración del texto de Galdós ${ }^{28}$ :

No es mi tutor. Es algo más. Es mi marido. Hace tiempo que quería confesártelo todo. Es que no estoy casada con mi marido, mejor dicho con mi tutor, digo, con ese hombre. No puedes imaginar cuánto he sufrido. Ya te he contado todo. Perdóname. Sé que estoy deshonrada, pero soy libre para quererte. ¿Te parece bien, o no podrás perdonarme? ¿Cómo me prefieres? ¿Como una casada infiel o libre? ¿Me sigues queriendo? ¡Habla! Dime algo, por favor. Yo sólo le engaño a él que no tiene ningún derecho sobre mí. Porque se lo merece. No sino lo quiero. A veces le odio por todo el daño que me ha hecho, y otras, lo confieso, sentía cariño por él, como un padre. Compréndelo. Si me hubiera querido como a una hija, otro gallo nos cantará. Tiene un lado bueno, pero el otro, vergüenza me da pensarlo. Cambia de cara como de camisa. Y cuando se trata de faldas... De veras, te aseguro que le odio con toda mi alma porque tú me has respetado, creyéndome inocente (...) Ya te he contado toda mi vida. Cuando me recogió, era muy joven. Una niña, comprendes.

Vemos que no se trata de citas rigurosas. Los diálogos fílmicos parecen citar la novela sin recurrir directamente a ella sino al recuerdo de su lectura.

Sin embargo, si el lector galdosiano tiene la sensación de estar en un universo diegético conocido, algunos desplazamientos de réplicas en el tejido fílmico pueden provocar cambios de sentido de estas citas. Por ejemplo, en la novela, Lope amenaza a Tristana y le prohíbe toda relación amorosa:

$\mathrm{Si}$ te sorprendo en algún mal paso, te mato, cree que te mato. Prefiero terminar trágicamente a ser ridículo en mi decadencia. Encomiéndate a Dios antes de faltarme. Porque yo lo sé, lo sé ; para mí, no hay secretos; poseo un saber infinito de estas cosas y una experiencia y un olfato..., que no es posible pegármela, no es posible ${ }^{29}$.

En la película, la réplica es casi idéntica ${ }^{30}$, pero aparece en la escena del parque, cuando Tristana conoce ya a Horacio. En este caso, se justifican las sospechas de Lope. No obstante, ya que en la novela el tutor amenaza a la joven antes de que haya conocido al pintor, el don Lope galdosiano aparece como un personaje más paranoico y patéticamente ridículo por su miedo al engaño ${ }^{31}$.

27 Ibid.

${ }^{28}$ Se nota también este fenómeno cuando Lope y Tristana discuten después del paseo nocturno de ésta con Horacio. Así, la joven dice a su tutor: «iY tú me hablas de honor! ¡Tú! ¡Eres el culpable de que lo haya perdido! ¡Si mi madre viera lo que has hecho de míl» Esta réplica retoma dos frases separadas del texto galdosiano. Ibid, p. 107 y p. 109. Benito PEREZ GALDOS, introducción de Ricardo Gullón, Op.cit., p. 70.

${ }^{29}$ Benito PEREZ GALDOS, introducción de Ricardo Gullón, Op.cit., p. 70.

${ }^{30} \mathrm{Si}$ te sorprendo en algún mal paso, te mato, creo que te mato. Prefiero una tragedia a ser ridículo en mi decadencia. Mira que para mí no hay secretos. Y con mi experiencia en esas cosas, es imposible pegármela. Es imposible.»

${ }^{31} \mathrm{Al}$ estudiar las adaptaciones de Buñuel, Antonio Monegal escribió: «(...) es como un proceso de adaptación y desplazamiento. Adaptar el texto supone apropiárselo, no como una obra fijada en un material, sino como el lugar de una lectura. Desplazarlo implica que en el mismo movimiento por el que se trasladan los signos se están alterando su sentido.» Antonio MONEGAL, Luis Buñuel, de la literatura al cine: una poética del objeto, Barcelona, Anthropos, 1993, p. 234 
Las citas de los diálogos literarios y los posibles desplazamientos de sentido consecutivos encuentran un cierto acabamiento con Ese oscuro objeto del deseo. En esta película, la gran mayoría de las réplicas aparecen en la novela de Louÿs bajo una forma ligeramente modificada ${ }^{32}$.

Este uso casi sistemático de los diálogos de la novela plantea el problema de las diferencias entre literatura y cine. Si tanto los diálogos literarios como cinematográficos tienen en común el objetivo de caracterizar de manera eficaz y rápida a los personajes dentro de un relato cuyos acontecimientos los determinan también -a diferencia del teatro donde los personajes y las situaciones se construyen sólo a través de los diálogos-, con las réplicas extraídas de las obras de Galdós y Louÿs, los dos filmes parecen reivindicarse como adaptaciones fieles. A propósito de Ese oscuro objeto, Jean-Claude Carrière habla de una «adaptación reconocida. Si hemos querido adaptar la novela, es porque nos interesaban elementos de ella. No hay reglas. Algunas adaptaciones retoman de manera más o menos fiel los diálogos de la novela ${ }^{33} \gg$. Sin embargo, la percepción del diálogo en el cine y en la literatura no es la misma. Citando a Eugene Vale, a Constance Nash y a Virginia Oakey, Michel Chion analiza así el diálogo cinematográfico:

Un buen diálogo no debe ser redactado en un estilo «escrito»o «literario». Como dicen Nash-Oakey, «Las palabras hechas para ser leídas y las hechas para ser dichas ne deben ser elegidas de la misma manera». Vale confirma que el texto del diálogo no debe tener la densidad de un texto escrito: «La palabra hablada no se percibe tan fácilmente (que el texto escrito) (...) Se disminuye rápidamente el poder de concentración del espectador.» Entonces habría que encontrar el equilibrio del diálogo entre la excesiva concentración del texto escrito, y el carácter demasiado diluída de la conversación «realista» ${ }^{34}$.

En las dos últimas adaptaciones de Buñuel, se nota lo novelesco en varias réplicas que, demasiado literarias, suenan extrañas. Por ejemplo, Mathieu confía a su primo Edouard: «Je respecte trop l'amour pour fréquenter les arrière-bou-tiques. Et je n'ai presque jamais possédé une femme sans l'aimer passionnément. Les autres, je peux les compter sur mes doigts $^{35}$.» Se empleaba a menudo a finales del siglo XIX la expresión «arrière-boutique» para

32 Por ejemplo, la madre demuestra así la inocencia de su hija Conchita en el texto de Louÿs: «Que faire? Moi, je n'ai pas de métier, je ne sais que m’occuper du ménage et prier la Sainte-Mère de Dieu. On m'a proposé une place de concierge, mais je suis trop fière pour être servante. Je passe mes journées à l'église. J'aime mieux baiser les dalles du Chœur que de balayer celle de la porte, et j'attends que notre Seigneur me soutienne au dernier moment. Deux femmes seules sont si exposées! Ah! Caballero, les tentations ne manquent pas à qui les écoute! Nous serions riches, ma fille et moi, si nous avions suivi les mauvais chemins. Nous aurions mules et colliers. Mais le péché n'a jamais passé la nuit ici. Notre âme est plus droite que le doigt de Saint Jean et nous gardons confiance en Dieu qui connaît les siens entre mille (...) Allez! ce qui perd les jeunes filles, ce sont les conseils des femmes plus que les yeux des hommes (...) Telle qui a le rosaire en main porte le diable dans sa jupe.» Pierre LOUYS, édition de Michel Delon, op.cit., pp. 74-75. Volvemos a encontrar estas frases en la boca de la madre y también de Conchita en las dos escenas de visita que devuelve Mathieu a las dos mujeres en su apartamento de París.

${ }^{33}$ Entrevista del 2 de julio de 2005

34 Michel CHION, Ecrire un scénario, Paris, Cahiers du cinéma/INA, 1985, p. 85. Michel Chion cita: Constance NASH, Virginia OAKEY, The Screenwriter's Handbook Writing for the Movies, New York, Barnes and Nobles Books, 1978, y Eugene VALE, The Technique of Screenplaywriting, An Analysis of the Dramatic Structure of Motion Pictures, London,

New York, Grosset and Dunlap, Souvenir Press LTD, 1980. Claire Vassé explica así esta diferencia de percepción: «(...) el diálogo cinematográfico no tiene la flexibilidad de la novela para penetrar la interioridad de los personajes, para pasar de una consciencia a la otra (...) el diálogo de cine, emanación de personajes inmersos en una situación, soporta difícil mente la conceptualización y la densidad intelectual. Además, desfila al ritmo de la bobina en el proyector, a la diferencia de la página de un libro leído al ritmo del lector.» Claire VASSE, Le dialogue, du texte écrit à la voix mise en scène, Paris, coédition Cahiers du cinéma/scéren-CNDP, 2003, (Collection pédagogique «Les petits cahiers»), p. 17

35 «Respeto demasiado el amor para acudir a trastiendas. Y casi nunca he poseído a una mujer sin quererla apasionadamente. Las otras, puedo contarlas con los dedos.» El texto original de Louÿs es: « Je respectais trop l'amour pour frequenter les arrière-boutiques, et je n'ai presque jamais possédé une femme que je n'eusse aimée 
designar un prostíbulo pero es anacrónica en la época de la película. Del mismo modo, en Sevilla, Conchita explica a Mathieu: «Je monte me reposer parce que l'on nous oblige dormir une demi-heure sinon on a des rêves sur la scène ${ }^{36} . »$ Usar la expresión «avoir des rêves» para decir sencillamente que uno tiene sueño, que está cansado, suena también raro en la boca de una joven de los años setenta.

En estos casos, el espectador siente la presencia de los orígenes literarios de la película, aunque no haya leído la novela. A pesar de querer lograr una obra personal, esta presencia parece implicar que en el proceso de la adaptación el texto literario es un obstáculo inevitable. Buñuel no logra borrar a Galdós ni a Louÿs y sin embargo hemos visto que los filmes se alejan libremente de los textos y traducen parcialmente el espíritu de las novelas. Este espíritu intentaría subsistir a través de los diálogos que constituyen la presencia intertextual de los textos de Galdós y Louÿs. Podemos hablar aquí de intertextualidad porque estos textos resisten al proceso de la adaptación -que tiene como objetivo crear un nuevo texto único y homogéneo a partir de una novela- y permanecen en el filme bajo la forma de citas, como otro texto, de manera a priori inalterada.

Así, los universos diegéticos propuestos por las películas se vuelven extraños. Profundamente buñuelianos, no dejan de reivindicar otras fuentes -las literarias- que sin embargo parecen ser, gracias a los desplazamientos estudiados, transformadas, modificadas, y al final subvertidas. Se trata de Galdós y Louÿs y, al mismo tiempo, no son realmente ellos.

\section{El misterio de las heroínas buñuelianas}

Por esta ambigüedad, Tristana y Ese oscuro objeto son películas misteriosas, tal como aparecen las nuevas heroínas creadas con referencia a sus antecedentes literarios. Si aquéllas no son el único elemento del discurso buñueliano que asegura la creación de lo extraño, la participación de las Tristana y Conchita cinematográficas en este fenómeno no deja de ser fundamental.

Primero, hay que subrayar la dimensión psicológica predominante de las dos obras de Galdós y Louÿs ${ }^{37}$. Tristana pone de relieve el interés del autor español por la psiquiatría y precisamente en este caso por el determinismo. Por culpa de la ruina de su padre, Tristana sufre de una educación insuficiente. Sin embargo, da pruebas de una gran curiosidad intelectual. Convencida de sus capacidades poco comunes, quiere que se reconozca su genio. Sin embargo, si tiene talento para la pintura como para los estudios, su imaginación demasiado desarrollada la aparta de la realidad y acelera su fracaso. Así, no entiende la joven que Horacio es sólo un pintor sin talento que busca una esposa y no una mujer desarrollada. Del mismo modo, no se entera de que los preceptos libertarios de Lope pueden ser puestos en práctica por un hombre del estatuto social de su tutor, pero que son imposibles en el caso de una mujer humilde. Al rechazar su fracaso, desarrolla un verdadero culto a su propia personalidad. Se deteriora la salud mental de Tristana que acaba por desarrollar un comportamiento hipómano -el mismo del que sufría su madre- que le hace multiplicar las nuevas iniciativas sin nunca cumplirlas. La amputación provoca una vuelta parcial a la realidad. Si abandona de repente toda ambición artística y olvida a Horacio, se apasiona por la figura de Cristo. Enamorada de un ser no terrenal, ya no le importa al final aceptar casarse con Lope. Al escribir el personaje de Tristana, no se trata para Galdós de denunciar un problema social, sino de describir y poner en escena una personalidad. La observación

pasionnément. Si je vous nommais cellelà, vous seriez surpris de leur petit nombre.» Pierre LOUYS, op.cit., p. 55.

36 «Subo a descansar porque nos obligan a dormir media hora porque sino tenemos sueño en el escenario.» El texto orig-inal de Louÿs es: «Quand nous avons bien dansé, m’expliquait-elle, on nous fait un peu dormir. Sans cela, nous aurions des rêves sur la scène. »Ibid, p. 111

37 Entendemos la intertextualidad tal como la define Genette: «(...) relación de copresencia entre dos o varios textos (...)gracias a la presencia efectiva de un texto en otro. Bajo su forma más explícita y más literal, es la práctica tradicional de la citación, (...) plagio (...), bajo una forma aún menos explícita y menos literal, la de la alusión.» Gérard GENETTE, Palimpsestes, Paris, Seuil, 1982, (Collection «Poétique»), p. 8 
psicológica adoptada para retratar a su heroína demuestra que el escritor no quiere preservar su misterio, sino que intenta al contrario hacer que su personalidad sea la más comprensible posible.

Del mismo modo, Conchita presenta un caso muy claro de masoquismo. Michel Delon define el relato de Pierre Louÿs y su descripción del personaje femenino como «el análisis de una perversión $n^{38}$ \%. Conchita es masoquista porque le proporciona placer el hacer sufrir al hombre que quiere -y a ella del mismo modo. En el amor, sólo puede ser víctima y se siente querida únicamente cuando Mateo la pega y la viola ${ }^{39}$. Si las motivaciones de la joven pueden parecernos a veces ambiguas, entre un amor inocente y una manipulación interesada, el final de la novela explica su comportamiento. A Conchita, no le interesa el dinero de Mateo, y nunca le ha engañado antes de que éste la violase ${ }^{40}$. Su masoquismo queda patente en las últimas páginas de la novela cuando Conchita provoca los celos de su amante solamente para que la pegue.

Entonces, en las dos novelas, se describen y se explican las perturbaciones psicológicas de las dos heroínas. Con Buñuel, éstas se vuelven mucho más misteriosas, aunque Tristana sigue intentando emanciparse sin lograrlo, mientras el propio director describe a Conchita como «sádica» $\mathrm{y}$ «masoquista ${ }^{41} »$.

Sin embargo, Tristana es misteriosa por su deseo de venganza que se confirma a lo largo de la película hasta el final cuando se convierte en el ángel exterminador de Lope. Por lo tanto, este aspecto respeta cierta coherencia psicológica. La actitud de Lope con ella al principio del filme puede explicar los actos de la heroína en la segunda parte. Al acusar a su tutor de ser el responsable de su destino trágico, decidiría destruírlo haciendo que se convirtiera en todo lo que aborrecía antes y dándole la muerte. Pero las desilusiones de Tristana no pueden explicar la transformación radical que experimenta el personaje.

Primero, la inocencia de la joven al principio de la historia, si constituye algo indiscutible en la novela, queda interrogada sutilmente con Buñuel. La relación que mantiene Tristana con Saturno es ambigua desde el comienzo. En la primera escena, le regala una manzana en la que el joven mudo muerde sin dejar de mirar a Tristana. El director no podía desconocer la simbólica bíblica de esta fruta, sobre todo si consideramos que en la novela Tristana regala una naranja, y no una manzana.

En la catedral, el comportamiento de Saturno va más allá de una simple mirada. Sin embargo, por haber acariciado sus caderas, éste recibe bofetadas pero nunca provoca la ira de Tristana que parece más bien divertirse. Desde el principio, la apariencia inocente y pura de la heroína no puede esconder totalmente cierto conocimiento del deseo masculino y de sus consecuencias. Así, cuando Saturno sale del baño en el que se había encerrado a pesar de la ira de su madre, los dos intercambian una breve mirada de connivencia.

Estos hechos interrogan también el comportamiento de Tristana con Lope. Si cuando éste la besa en la catedral, la joven parece verdaderamente turbada e inconsciente de lo que está pasando, no deja por lo tanto de manipular a su tutor. Durante la cena en la que Lope le ofrece el único huevo que queda en casa, las lágrimas de la heroína parecen fingidas para provocar su compasión. De hecho, en la escena siguiente, la vemos paseándose con Lope después de que éste le haya comprado nuevos trajes. Sin embargo, nunca vemos a Tristana agradecer a su tutor y, aun más, si hasta su huida con Horacio jamás aparece en dos escenas distintas con el mismo vestido, sólo califica a Lope de «viejo» y «ridículo».

No obstante, su destino va vinculado a su tutor, y el viaje a Madrid con Horacio -cambio importante de Buñuel y Alejandro- parece tener como función demostrárnoslo. Tristana

\footnotetext{
38 Pierre LOUYS, édition de Michel Delon, op.cit., p. 9.

39 «Oh! Mateo! Comme tu m'aimes! », murmura ella cuando Mateo la pega por primera vez. Ibid, p. 133 133.

40 Mateo lo subraya cuando lo cuenta a André Stévenol: «(...) en effet, Monsieur, elle était vierge...» Ibid, p.

${ }^{41}$ Tomás PEREZ TURRENT, José DE LA COLINA, op.cit., p. 175
} 
podía quedarse con el pintor ${ }^{42}$, y prefiere romper esta relación y quedarse en casa de Lope con el cual se va a mostrar cada vez más vindicativa.

Al destruír a Lope y a sí misma, Tristana podría ser masoquista. Sin embar-go, otro elemento aportado por los guionistas nos impide adherirnos totalmente a esta lectura psicoanalítica. Se trata de las extrañas premoniciones que manifi-esta la joven a propósito de Lope. ¿Por qué de pequeña lo huía «como si hubiera visto al diablo ${ }^{43}{ }^{\prime}$ y por qué sueña con su cabeza cortada cuando de momento su tutor ha tenido siempre un comportamiento muy respetuoso con ella? Se repite esta imagen onírica a lo largo de la película y parece anunciar la de la muerte de Lope ${ }^{44}$.

No obstante, si Tristana parece ver inconscientemente a su tutor como una amenaza, es fascinada también por el retrato de la mujer que encuentra al ayudar a Saturna en las tareas domésticas. Después de que la criada le haya contado el escándalo provocado por la relación que mantuvo Lope con esta señora ${ }^{45}$, Tristana manifiesta su turbación tirando al suelo el frasco de disolvente ${ }^{46}$. Exper-imentando a la vez deseos de sexo y de muerte ${ }^{47}$, la heroína realizaría durante la película lo que constituye su inconsciente y que suponemos a través de estos escasos indicios.

El misterio de Tristana estriba en el hecho de que no podemos determinar en qué medida sus pulsiones han determinado su comportamiento sin que fuera consciente de ellas, o si pudo enterarse de sus deseos y realizarlos en plena con-ciencia ${ }^{48}$. La ambigüedad proviene de su obsesión por poder siempre elegir en su existencia. Rechazando el azar, Tristana quiere controlarlo todo y elegir incluso entre dos cosas idénticas, como dos columnas, dos garbanzos o dos calles de las cuales una la lleva a Horacio. Esta obsesión podría responder a una necesidad inconsciente de escapar del destino que se anuncia en sus sueños premonitorios, de escapar de sus fantasías y deseos morbosos, o al contrario podría expresar la voluntad de dominar su destino para satisfacer todas sus pulsiones. Así, anali za Freud la obsesión por la elección: «La elección reemplaza la necesidad, la fatalidad. De este modo, el hombre supera la muerte que ha reconocido en sus pensamientos. No se puede concebir triunfo más rotundo del cumplimiento del deseo. ${ }^{49}{ }$ Verdugo y víctima, Tristana ha sido los dos, pero no sabemos exacta-mente en qué medida.

La Conchita de Ese oscuro objeto reproduce el mismo comportamiento masoquista al mantener una relación con un hombre que provoca en ella sen-timientos contradictorios de

${ }^{42}$ Cuando habla con Lope, Horacio lo deja bien claro: «Le he pedido muchas veces a Tristana que se casara conmigo pero ella siempre se ha negado (...) Ella se empeñó en venir. Insistió hasta volverme loco (...) Quiere morirse en su casa (...) No estoy tratando de abandonarla.»

${ }^{43}$ Lope le dice: «Chillabas como si hubieras visto al diablo. Me acuerdo cuando eras pequeña, que al verme empezabas a chillar, exactamente como ahora.»

${ }^{44}$ Debajo de las mantas, deja ver sólo su cabeza. Además, su gorra de noche puede evocar la campana del sueño

45 Saturna le cuenta: «Era una Señora (...) casada con un marqués, pero se metió don Lope por en medio y ¡fas! (...) Fue una cosa muy sonada, hasta en los papeles vino. Mejor que el Señor, no lo hay, pero cuando ve una falda, le apuntan los cuernos y la cola.»

46 En Belle de Jour, Séverine -interpretada también por Catherine Deneuve- manifiesta igualmente su disturbio cuando recuerda que de niña la besó un fontanero

47 Esta doble dimensión queda bien clara en la imagen de la cabeza cortada de don Lope que aparece al principio y al final de la película. Pedro Poyato puntualiza que, si la primera vez la imagen irrumpe cuando «Tristana (...) llevaba las manos hasta el gran badajo, de marcada forma peniana (...) para mecerlo ligeramente», al final, «son las (calidades) de la muerte las vinculadas a esta recurrente imagen (...) la muerte asociada a la noche y al frío, al fondo negro y al silen-cio, como también a la voz agonizante de don Lope llamando a Tristana». Pedro POYATO, El sistema estético de Luis Buñuel, Bilbao, Universidad del País Vasco, 2011, p. 176.

48 Cuando charla con don Ambrosio, vemos que sabe analizar sus sentimientos: «No me hable de médico. Lo que necesito es otra cosa (...) ¿Cóme me voy a casar con él si no lo puedo ni ver? (...) Cuanto mejor es, lo quiero menos.»

49 Sigmund FREUD, «Le motif du choix des coffrets», L'inquiétante étrangeté et autres essais, Paris, Gallimard, 1985, (Collection «Folio essais»), pp. 61-81, p. 78 
amor y de odio. Huye de él cuando se pone demasi-ado cariñoso, pero le da su dirección cuando lo reencuentra en Suiza. Le divierte hacerle sufrir y se tortura al mismo tiempo convenciéndose de que no la quiere. «Tu sais, Mathieu», le dice, «ce que je fais, moi non plus, je ne l'aime pas. Et toi, ce que tu aimes c'est ce que je te refuse, ce n'est pas moi ${ }^{50}$.» Incluso le da placer aparecer como una vulgar intrigante: «'ai prié Dieu pour que tu meures après que je t'aurais ruiné ${ }^{51} \gg$ La desmiente el desarrollo de la película, pero no del todo. Si sabemos que el dinero no le interesa, ya que devuelve a Mathieu las llaves de la casa de Sevilla, no sabemos hasta qué punto era sincera cuando le decía quererle y ser virgen.

La relación de Conchita con El Morenito interroga su sinceridad. Que vaya a Suiza o a España, el joven va con ella. En el piso de Mathieu, si la negativa de Conchita ha podido convencernos de su virtud, la llegada del Morenito lo cam-bia todo en la escena siguiente.

Mientras que en la novela Mateo confiesa que efectivamente Conchita era virgen cuando la violó, el juego establecido en el filme entre el relato primero y el relato segundo enunciado por Mathieu nos impide conocer la verdad. En la escena al principio de la película cuando el protagonista vuelve al cuarto en el que se ha peleado con Conchita, todos los indicios encontrados por el mayordomo parecen dejar claro que Mathieu ha violado a la joven. Además, la sangre sobre el cojín demostraría su virginidad y entonces su sinceridad. Sin embargo, al final de la película, asistimos a la audiovisualización de la pelea mientras Mathieu la está contando en el tren, y vemos que Conchita echa sangre por la nariz. Desde luego, aunque la hubiera violado, el personaje no podía contarlo a desconocidos, pero varias veces el filme nos ha demostrado que lo que veíamos en la pantalla no podía corresponder del todo al relato oral de Mathieu. Entonces, ¿por qué en esta secuencia el discurso audiovisual adoptaría la mentira del personaje? Así, es imposible determinar en qué medida Conchita se burló de Mathieu, si lo ha engañado con el Morenito o si lo quiere ${ }^{52}$.

El carácter indefinible de Conchita queda subrayado por su doble inter-pretación. Con Carole Bouquet y Ángela Molina, Buñuel reúne a dos actrices muy opuestas pero nunca considera estas diferencias a la hora de decidir de las apariciones de las dos. Sabía que repartir las escenas entre ellas según la elegancia fría de la una o el carácter más pasional de la otra habría creado dos visiones distintas del personaje. Al establecer una repartición que jamás consti-tuye un sistema que permita al espectador entender mejor a Conchita, esta doble interpretación no tiene en cuenta los estereotipos propuestos por la imagen de las actrices y, gracias a esta falta de lógica representativa, el cineasta permite la mezcla de las dos imágenes sin por lo tanto cancelar la dualidad del personaje. Esta queda más bien acentuada por el hecho de que se instala al espectador en un universo inestable donde no puede prever cuándo una actriz va a sustituirse a la otra. De nuevo, la heroína, al trasladarse de la novela a la pantalla, pierde de su coherencia y gana en misterio ${ }^{53}$.

Estos dos personajes femeninos, al ser el objeto de una descripción psicológica por parte de Galdós y Louÿs, presentan rasgos humanos que permiten la ilusión referencial y nuestra adhesión al universo diegético propuesto. No obstante, si con Buñuel podemos reconocer en las heroínas fílmicas a sus antecedentes literarios como una referencia original, el director provoca este reconocimiento sólo para atraernos mejor en un universo que se vuelve inquietante y que interroga nuestras representaciones y creencias, gracias a sutiles desplazamientos de sentido. Las heroínas buñuelianas se vuelven así turbadoras, como las analiza Carlos Saura: «(...) la mujer como un ser extraordinario, fuera de la normalidad, llena de virtudes (o de defectos), pero nunca un ser equilibrado, normal y equivalente. Esto

50 «A mí tampoco me gusta lo que estoy haciendo. Y a ti, lo que te gusta no soy yo, sino lo que te niego.»

51 «He rezado para que te murieras después de que te hubiera arruinado.»

52 En la medida en que la complejidad de la Conchita buñueliana va más allá de la de Louÿs, cabe citar a Pedro Poyato, cuando éste subraya, en la creación de la heroína fílmica, la influencia de la Carmen de Mérimée y, sobre todo, de Pandora. Leer: Pedro POYATO, op.cit., pp. 185-199.

${ }^{53}$ Este juego tiene como objetivo impedir al espectador tener una comprensión coherente del personaje, ya que sólo el espectador nota la alternancia de los dos rostros, a la diferencia de los otros personajes que nunca expresan la menor sorpresa o duda. 
nunca ${ }^{54} . »$ Las películas de Luis Buñuel proponen al espectador un mundo extraño que remite a lo que presenta Freud como el «inquietante extrañamiento» que «(...) sería siempre algo en el que (...) nos encontramos desorientado. Mejor un hombre se sitúa en su entorno, menos podrá recibir de las cosas o de los acontecimientos que se producen allí una impresión de inquietante extrañamiento ${ }^{55}$ ». Así, Tristana y Ese oscuro objeto del deseo pueden aparecernos como adaptaciones fieles de las novelas de Galdós y Louÿs, tan fieles que, al utilizar los diálogos literarios, se presentan como una puesta en imagen rigurosa que nos aleja de un modelo de adaptación tradicional. Sin embargo, son al mismo tiempo obras muy personales en las que queda inevitable la presencia de Buñuel. Los filmes propuestos oscilan entonces entre diversas fuentes autorales. Además, todo lo que tenía un sentido en las novelas es interrogado por las películas que no proponen ninguna respuesta. Gracias a este misterio que no se puede resolver, el resultado fílmico queda entre el respeto a los textos originarios y la reinterpretación. Al ser no definibles, las obras buñuelianas logran el carácter extraño del cual habla Freud. En este proceso, los textos literarios no han sido solamente la propuesta de una historia, sino que sus relatos han servido como una referencia reconocible según los espectadores, respetada y no respetada a la vez y que ha participado en la subversión buñueliana del discurso cinematográfico.

${ }^{54}$ Manuel RODRIGUEZ BLANCO, Luis Buñuel, Paris, Bibliothèque du film, Courbevoie, Durante, 2000, p. 190

55 Sigmund FREUD, art.cit., p. 216. 